Old Dominion University

ODU Digital Commons

OEAS Faculty Publications

Ocean, Earth \& Atmospheric Sciences

9-1991

\title{
Lava-Seawater Interactions at Shallow-Water Submarine Lava Flows
}

\author{
Francis J. Sansone \\ Joseph A. Resing \\ Gordon W. Tribble \\ Peter N. Sedwick \\ Old Dominion University, Psedwick@odu.edu \\ Kevin M. Kelly \\ See next page for additional authors
}

Follow this and additional works at: https://digitalcommons.odu.edu/oeas_fac_pubs

Part of the Biogeochemistry Commons, and the Oceanography Commons

\section{Repository Citation}

Sansone, Francis J.; Resing, Joseph A.; Tribble, Gordon W.; Sedwick, Peter N.; Kelly, Kevin M.; and Hon, Ken, "Lava-Seawater Interactions at Shallow-Water Submarine Lava Flows" (1991). OEAS Faculty Publications. 142.

https://digitalcommons.odu.edu/oeas_fac_pubs/142

\section{Original Publication Citation}

Sansone, F. J., Resing, J. A., Tribble, G. W., Sedwick, P. N., Kelly, K. M., \& Hon, K. (1991). Lava-seawater interactions at shallow-water submarine lava flows. Geophysical Research Letters, 18(9), 1731-1734. doi: 10.1029/91GL01279

This Article is brought to you for free and open access by the Ocean, Earth \& Atmospheric Sciences at ODU Digital Commons. It has been accepted for inclusion in OEAS Faculty Publications by an authorized administrator of ODU Digital Commons. For more information, please contact digitalcommons@odu.edu. 
Authors

Francis J. Sansone, Joseph A. Resing, Gordon W. Tribble, Peter N. Sedwick, Kevin M. Kelly, and Ken Hon 


\title{
LAVA-SEAWATER INTERACTIONS AT SHALLOW-WATER SUBMARINE LAVA FLOWS
}

\author{
Francis J. Sansone ${ }^{1}$, Joseph A. Resing ${ }^{1}$, Gordon W. Tribble ${ }^{1,2}$ \\ Peter N. Sedwick ${ }^{1}$, Kevin M. Kelly ${ }^{1}$, and Ken Hon $^{3}$
}

\begin{abstract}
Hydrothermal plumes associated with nearshore lava flows from Kilauea Volcano, Hawaii were studied on five occasions during 1989-1990 to address the current lack of data on direct lava-seawater interactions. The following enrichments were found in the sea-surface hydrothermal plumes above the active underwater lava flows: $\mathrm{H}_{2}, 15,000 \mathrm{x}$ ambient seawater concentrations; $\mathrm{Mn}, 250 \mathrm{x}$; and $\mathrm{Si}, 20 \mathrm{x}$. Water temperatures reached $46^{\circ} \mathrm{C}$. Lower concentrations and temperatures were observed in the plumes with increasing distance from shore, with $\mathrm{H}_{2}$, Si, and $\mathrm{Mn}$ concentrations linearly related to seawater temperature. Unlike deep sea spreading center hydrothermal plumes, no $\mathrm{CH}_{4}$ enrichment was observed. The elevated $\mathrm{H}_{2}$ is likely to be from water-rock reactions, rather than from the release of magmatic gas. The plume mass/heat ratios presented here suggest that submarine flood basalts, although aerially large, should be relatively small immediate contributors to oceanic geochemical cycles compared to hydrothermal circulation through the crust.
\end{abstract}

Introduction

Direct lava-seawater interactions in the vicinity of Kupapau Point on the southeast coast of the island of Hawaii $\left(19^{\circ} 20^{\prime} \mathrm{N}, 155^{\circ} 1 \mathrm{~W}\right)$ were studied on five occasions. The eruption responsible for these flows from Kilauea Volcano has been extruding lava at an average rate of $4.5 \times 10^{5} \mathrm{~m}^{3} \mathrm{day}^{-1}$ since mid-1983 (Wolfe et al., 1987). The magma reaches the surface at Puu Oo cinder cone, where the bulk of magmatic volatiles is vented to the atmosphere (Gerlach and Taylor, 1990). Subsurface tubes then supply this lava to downslope flows, some of which extend offshore (Greenley, 1987).

Five modes of lava-seawater interaction have been observed at this site (Tribble, 1991): 1) shoreline lava flows, 2) submarine pillow lavas, 3) submarine channelized lava flows, 4) hydrothermal jets from seawater contact with buried submarine lava tubes, and 5) explosions at the surface of fluid underwater flows, thought to be caused by the ignition of hydrogen-rich gases produced by lavaseawater reactions (see below). The hot water from these processes forms $\leq 3$-m thick surface plumes that can be observed to extend seaward from the shore (Sansone et al., 1990b).

These plumes have a distinct greenish-gray color, with the hottest water being light brown. Very sharp gradients exist between the plume and the clear blue surrounding seawater. A colored plume typically extends a kilometer or less alongshore, and may stretch more than a kilometer offshore depending on the nearshore currents. This altered seawater has high levels of suspended black glass fragments released during the fracturing of hot lava in contact with seawater. On several occasions large concentrations of gelatinous zooplankton were also observed. The light attenuation anomalies in the surface plume can reach values of $9 \mathrm{~m}^{-1}(10 \%$

\footnotetext{
${ }^{1}$ Department of Oceanography, University of Hawaii at Manoa

${ }^{2}$ Water Resources Division, U.S. Geological Survey

${ }^{3}$ Hawaiian Volcano Observatory, U.S. Geological Survey
}

Copyright 1991 by the American Geophysical Union.

Paper number 91GL01279

0094-8534/91/91GL-01279\$03.00 light transmission over $25 \mathrm{~cm}$ ) (data not shown). Finally, it is not uncommon for several lava outbreaks to occur along a few $\mathrm{km}$ of shoreline, with individual plumes emanating from each outbreak.

A hull-mounted thermistor (precision $= \pm 0.05^{\circ} \mathrm{C}$ ) was used to measure the temperature of the surface plumes. Positioning was obtained $( \pm 2 \mathrm{~m})$ with a Motorola Mini-Ranger Falcon-IV. Samples were collected with a 2.5 -liter Go-Flo bottle. $\mathrm{H}_{2}$ was measured $( \pm 15 \%)$ within one day of collection by gas-chromatography(GC)/ UV-photometry (Bullister et al., 1982). $\mathrm{CH}_{4}$ was determined $( \pm 1 \%)$ by cold-trap/GC (Brooks et al., 1981). Dissolved inorganic nutrients $\left(\mathrm{PO}_{4}( \pm 0.02 \mu \mathrm{M}) ; \mathrm{NH}_{4}, \mathrm{NO}_{3}+\mathrm{NO}_{2}\right.$, and $\mathrm{Si}( \pm 0.03$ $\mu \mathrm{M})$ ), dissolved organic $\mathrm{P}( \pm 0.04 \mu \mathrm{M})$, and dissolved organic $\mathrm{N}$ $( \pm 0.6 \mu \mathrm{M})$ were measured on filtered samples $(0.2 \mu \mathrm{m}$ pore size $)$ using standard techniques (Parsons et al., 1984) with a Technicon AutoAnalyzer II, except for September 1990 Si samples, which were measured $( \pm 3 \%)$ by flow injection analysis. $\mathrm{Mn}$ and $\mathrm{Li}$ in filtered samples were determined $( \pm 10 \%)$ by direct injection furnace atomic absorption spectroscopy (Carnrick et al., 1981). Class-100 conditions were used for trace element sample preparations; acid-washed polypropylene and polycarbonate apparatus were used for sample collection and filtration; North Atlantic Standard Seawater and Coastal Atlantic Standard Seawater (National Research Council, Canada) were used as standards.

\section{Results and Discussion}

The surface seawater temperature for the Kupapau Point region on 11 June 1989 shows the localized nature of the lava activity on this day (Figure 1a); the maximum surface water temperature recorded was $38^{\circ} \mathrm{C}$ approximately $100 \mathrm{~m}$ offshore of the shoreline lava flows. Vigorous underwater lava flows were also observed by SCUBA divers below this point. In contrast, lava-induced surface seawater temperature anomalies were seen six weeks later across a 3-km length of coast (Figure 1b), the result of major nearshore and shoreline lava flows at the ends of this section, with smaller flows in between. The maximum surface water temperature measured on this day was $44^{\circ} \mathrm{C}$.

The dissolved $\mathrm{H}_{2}$ and $\mathrm{CH}_{4}$ concentrations of surface seawater samples collected from thermal plumes on the five sampling dates are plotted $v s$. water temperature anomaly $(\Delta T)$ in Figure 2. An extrapolation of the $\mathrm{H}_{2}$ regression line to $\Delta \mathrm{T}=110^{\circ}\left(135^{\circ} \mathrm{C}\right.$, the boiling point of seawater at the $\sim 21 \mathrm{~m}$ depth of the major nearshore lava-seawater contact (Stoughton and Lietzke, 1967)) yields a hypothetical "endmember" $\mathrm{H}_{2}$ concentration of $11 \mu \mathrm{M}$. This value is within the range of $1-1700 \mu \mathrm{M}$ found in endmember fluids from spreading center (deep-sea) hydrothermal vents (Welhan and Craig, 1983; Lilley et al., 1983). In contrast, $\mathrm{CH}_{4}$ concentrations in the Kupapau plumes were not significantly greater than the low $\mathrm{nM}$ levels typically found in nearshore Hawaiian waters (Figure 2). This result is in marked contrast to the elevated $\mathrm{CH}_{4}$ levels $(50-1400 \mu \mathrm{M})$ reported for endmember fluids from spreading center hydrothermal vents (M.D. Lilley, pers. comm.; Welhan and Craig, 1983; Lilley et al., 1983).

Note that our use of $135^{\circ} \mathrm{C}$ as the temperature of the hydrothermal "endmember" in our system does not imply that this is necessarily the temperature of the water-rock reactions. The 

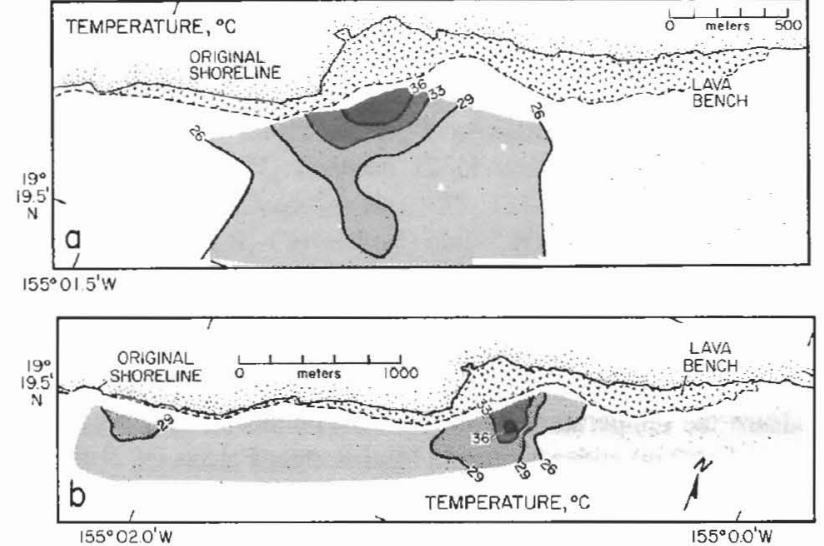

Fig. 1. The temperature distribution in surface seawater at Kupapau Point on a) 11 June 1989 and b) 26 July 1989. The shading indicates the areas surveyed (cruise track interval $\leq 100 \mathrm{~m}$ ).

contact between incandescent lava and seawater undoubtedly results in temperatures well in excess of the ambient boiling point, and likely results in high temperature steam-lava/steam-rock reactions (see below). SCUBA divers at this site regularly observe the release of what appears to be steam from the seawater-lava contact; the steam rises several $\mathrm{cm}$ from the contact before it is quenched by the surrounding seawater (Sansone et al., 1990a). The $135^{\circ} \mathrm{C}$ "endmember" is used in this study to determine the composition of the seawater immediately above the seawater(-steam)-lava contact.

Large numbers of gas bubbles were released to the overlying seawater, with some reaching the atmosphere. The major sources of gas bubbles included the contact of incandescent channelized lava flows and pillow lavas with seawater, underwater hydrothermal jets, and explosions occurring on fluid lava flows. Five samples of bubbles were collected immediately over a variety of lava flows by divers with inverted bottles. The bubbles were 14$25 \% \mathrm{H}_{2}(\mathrm{v} / \mathrm{v}), 19-22 \% \mathrm{O}_{2}, 49-64 \% \mathrm{~N}_{2}, 1-9 \% \mathrm{CO}_{2}$, and $40-79$ ppm $\mathrm{CH}_{4}$ (T. Lorenson and W. Evans, pers. comm.).

These high levels of $\mathrm{H}_{2}$ cannot solely result from the release of magmatic gas because the latter contains much lower $\mathrm{H}_{2}$ levels: Kilauea magmatic gas is $0.1-1.5 \% \mathrm{H}_{2}$ (Greenland, 1987). We believe that the $\mathrm{H}_{2}$ in the seawater plume and the gas bubbles is primarily due to water-rock reactions (e.g., Christie et al., 1986). Note that such processes are not limited to liquid-solid reactions: the production of $\mathrm{H}_{2}$ from $\mathrm{Fe}$ oxidation by steam at $700^{\circ} \mathrm{C}$ and 1 atm is well established (Deming, 1935). Finally, our hypothesis is also consistent with the above-mentioned venting of volatiles from Kilauea magma at Puu $\mathrm{O}$ o before it is extruded at the shore.

The low $\mathrm{CH}_{4}$ levels in the bubbles are similar to those in Kilauea magmatic gas (e.g., Greenland, 1987). It is likely that the low $\mathrm{CH}_{4}$ levels in the surface plumes simply reflect the low $\mathrm{CH}_{4}$ concentrations existing during rock-water equilibria at elevated temperature and low pressure (Gerlach, 1980). This would also explain the significantly higher levels of $\mathrm{CH}_{4}$ observed in deep sea hydrothermal fluids, because rock-water $\mathrm{CH}_{4}$ production is significant only under elevated hydrostatic pressures (Gerlach, 1980). Note, however, that $\mathrm{H}_{2}$ production is not similarly constrained by pressure (T.M. Gerlach, pers. comm.).

Except for a marked increase in dissolved Si (Figure 2), there was not a significant change in organic or inorganic nutrients in the surface plumes from ambient seawater levels (data not shown). $\mathrm{Li}$ also remained at background nearshore levels $(\sim 25 \mu$ mole $/ \mathrm{kg}$, data not shown). In contrast, dissolved Mn was significantly enriched in the plumes (Figure 2). Extrapolation of the Si (solid line) and $\mathrm{Mn}$ regressions in Figure 2 to $\Delta \mathrm{T}=110^{\circ}\left(135^{\circ} \mathrm{C}\right)$ yields hypothetical
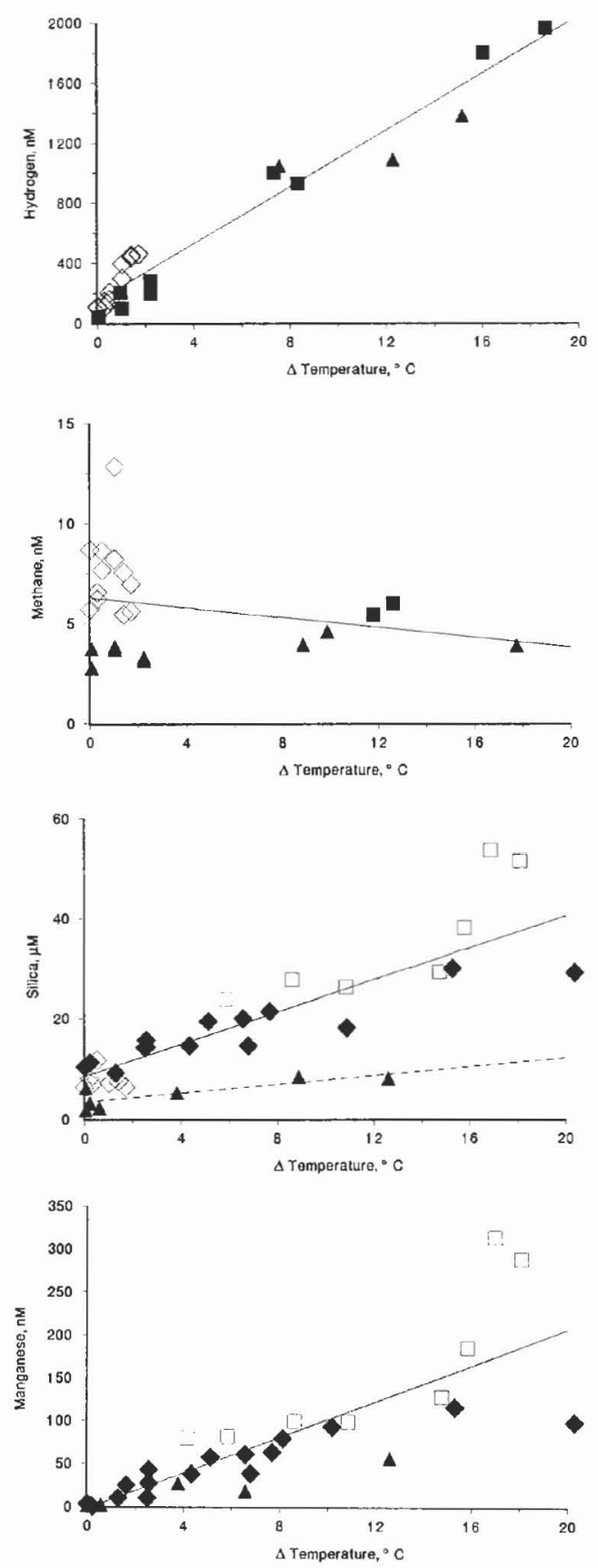

Fig. 2. Dissolved $\mathrm{H}_{2}, \mathrm{CH}_{4}, \mathrm{Si}$ and $\mathrm{Mn} v s . \Delta \mathrm{T}$ (with respect to offshore surface seawater) for surface seawater samples. Data from

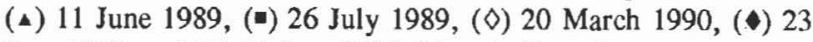
Sept 1990, and (ㅁ) 24 Sept 1990. Lines indicate least square linear regressions with the following slopes: $\mathrm{H}_{2}, 95 \mathrm{nM}^{\circ} \mathrm{C}^{-1} ; \mathrm{CH}_{4},-0.12$ $\mathrm{nM}{ }^{\circ} \mathrm{C}^{-1} ; \mathrm{Si}, 0.44 \mu \mathrm{M}{ }^{\circ} \mathrm{C}^{-1}$ (dashed line, June 1989 data), 1.6 $\mu \mathrm{M}$ ${ }^{\circ} \mathrm{C}^{-1}$ (solid line, all other data); and $\mathrm{Mn}, 11 \mathrm{nM}^{\circ} \mathrm{C}^{-1}$.

"endmember" concentrations of $190 \mu \mathrm{M} \mathrm{Si}$ and $1.2 \mu \mathrm{M} \mathrm{Mn}$. Both values are several orders of magnitude lower than those reported for high temperature spreading center hydrothermal vent endmembers (e.g., Von Damm et al., 1987). It is likely that this difference is largely due to the very short water-rock reaction time in our system. For example, Seyfried et al. (1984) found that Li concentrations in seawater in contact with basalt glass at $150^{\circ}$ and 500 bar do not increase until after 30 hours. 
TABLE 1. Ranges of mass/heat ratios for seawater alteration at deep sea hydrothermal systems and Hawaiian surface plumes.

\begin{tabular}{|c|c|c|c|c|c|}
\hline Hydrothermal system & $\begin{array}{l}\mathrm{H}_{2} / \text { heat } \\
(\mathrm{pmol} / \mathrm{J})\end{array}$ & $\begin{array}{l}\mathrm{CH}_{4} / \text { heat } \\
(\mathrm{pmol} / \mathrm{J})\end{array}$ & $\begin{array}{l}\text { Si/heat } \\
(\mathrm{nmol} / \mathrm{J})\end{array}$ & $\begin{array}{l}\text { Mn/heat } \\
(\mathrm{pmol} / \mathrm{J})\end{array}$ & Reference \\
\hline Spreading center high-T vent fluid & $184-858^{*}$ & $18-34^{*}$ & $7-23$ & $290-3500$ & $\begin{array}{l}\text { Welhan and Craig, 1983; Von } \\
\text { Damm et al., 1985, } 1987\end{array}$ \\
\hline Spreading center low-T vent fluid & $0.5-4.7^{*}$ & $65-220^{*}$ & 14 & $360-930$ & $\begin{array}{l}\text { Corliss et al., 1979; Lilley } \\
\text { et al., } 1983\end{array}$ \\
\hline Spreading center plume & & $9.5-1600$ & & $170-840$ & $\begin{array}{l}\text { Baker and Massoth, 1986; Baker } \\
\text { et al., 1987; Charlou et al., } \\
\text { 1988; Kadko et al., } 1990\end{array}$ \\
\hline Spreading center megaplume & & & 10 & 88 & Baker et al., 1987 \\
\hline Mid-plate plume (Loihi, Hawaii) & & $78-88$ & & & Gamo et al., 1987 \\
\hline Hawaiian surface plumes & 22 & $\sim 0$ & $0.10-0.38$ & 2.5 & This work \\
\hline
\end{tabular}

High-T ratios calculated using heat capacity data of Bischoff and Rosenbauer (1985); surface plume ratios from regressions in Figure 2. ${ }^{*}$ Calculated assuming excess heat $=1.9 \times 10^{17} \mathrm{~J} / \mathrm{mol}^{3}{ }^{3} \mathrm{He}$ (Jenkins et al., 1978).

The "endmember" concentrations computed from our samples are similar to those of seawater emanating from hydrothermal jets located at $\sim 21 \mathrm{~m}$ depth at this site (Sedwick et al., 1991). These waters had lowered $\mathrm{pH}$ values ( 6.5 ) and had dissolved $\mathrm{Si}$ and $\mathrm{Mn}$ concentrations of $9-143 \mu$ mole $\mathrm{kg}^{-1}$ and $73-1290 \mathrm{nmol} \mathrm{kg}$, respectively. This heated seawater was apparently subjected to boiling, as evidenced by the steam observed in the jets' effluent, and chloride enrichment in the heated seawater (up to $19.13 \mathrm{~g} \mathrm{~kg}^{-1}$, as compared to an ambient concentration of $19.02 \mathrm{~g} \mathrm{~kg}^{-1}$ ).

The lava extrusion rate from Kilauea Volcano during mid-1989 was 2.5-3.0 $\times 10^{5} \mathrm{~m}^{3} \mathrm{day}^{-1}$, with approximately $20-30 \%$ of the lava entering the ocean (Kelly et al., 1989). Assuming a lava temperature of $1130^{\circ} \mathrm{C}$ (D.M. Thomas, pers. comm.), a lava specific heat of cooling of $3.8 \mathrm{~J} \mathrm{~cm}^{-3} \mathrm{deg}^{-1}$, and a lava latent heat of crystallization of $10^{3} \mathrm{~J} \mathrm{~cm}^{-3}$ (Baker et al., 1987), this represents a heat input to the ocean of 2.6-4.7 $\times 10^{14} \mathrm{~J} \mathrm{day}^{-1}$. This computed heat flux is smaller than those for spreading center hydrothermal "megaplumes" $\left(6-60 \times 10^{15} \mathrm{~J} \mathrm{day}^{-1}\right)$ (Baker et al., 1989), but is larger than those measured for individual spreading center vents $\left(4.3 \times 10^{10}-2.2 \times 10^{13} \mathrm{~J} \mathrm{day}^{-1}\right)$ (Converse et al., 1984).

The above calculations assume negligible heat losses from the surface plume to the atmosphere. Although these losses cannot be accurately estimated at this time, the very good linearity for $\Delta \mathrm{T} v s$. $\mathrm{H}_{2}$ and $\mathrm{Si}$ (Figure 2) argue that temperature must be quite conservative over the time and space scales of our observations.

Using the relationship between $\Delta \mathrm{T}$ and $\mathrm{H}_{2}$ (Figure 2), a $\mathrm{H}_{2}$ flux of $6.2-11 \times 10^{3} \mathrm{~mol} \mathrm{day}^{-1}$ can be computed from the heat flux calculated above. Data are not available to compare this $\mathrm{H}_{2}$ flux with those for spreading center systems, but it is clear that it is small on a global scale: the total flux of $\mathrm{H}_{2}$ from the ocean to the atmosphere $-3 \times 10^{9} \mathrm{~mol} \mathrm{day}^{-1}$ (Jørgensen, 1982).

A comparison of mass/heat ratios for a variety of hydrothermal systems shows that there are distinct differences between the Kilauea surface plumes and other systems (Table 1). The very low $\mathrm{Si} /$ heat and $\mathrm{Mn} /$ heat ratios for the Kilauea plumes indicate that the hydrothermal extraction efficiencies are relatively low for these elements, despite the high reaction temperatures implied by direct lava-seawater contact. The low ratios are likely due to the short contact time of seawater with the lava before the latter is cooled.

These mass/heat ratios can be used to infer the importance of submarine lava-seawater interactions on global geochemical cycles. For example, recent reports have drawn attention to the existence of large scale submarine flood basalts that appear to be of relatively recent origin, and which may have been responsible for large heat inputs to the ocean (e.g., Davis, 1982; Shaw and Moore, 1988). Using a global submarine lava extrusion rate of $3.3 \mathrm{~km}^{3} \mathrm{y}^{-1}$ (Crisp, 1984), a global heat flux of $1.8 \times 10^{19} \mathrm{~J} \mathrm{yr}^{-1}$ can be calculated, which is only $10 \%$ of the estimated global spreading center hydrothermal heat flux of $2.1 \times 10^{20} \mathrm{~J} \mathrm{yr}^{-1}$ (Jenkins et al., 1978). This result, combined with the low extraction efficiencies computed for lava-seawater interactions (Table 1), suggest that immediate global chemical fluxes due to submarine lava extrusions are much smaller than those for spreading center hydrothermal systems.

Nevertheless, submarine lava extrusions may be geochemically important on a regional scale. For example, as seen here, elements such as Si that are depleted in surface seawater may experience significant enrichment in the vicinity of shallow lava-seawater interactions. Continuing reports of sea surface hydrothermal activity related to shallow water volcanism (e.g., McClelland $e t$ $a l ., 1989)$ suggest that upper ocean volcanism may be relatively widespread.

Acknowledgements. We thank Capt. R. Kawamoto for skillful piloting; S.V. Smith, R. Feely, M. Mottl, T. Gerlach, C. Measures, and H.-J. Krock for valuable discussions; T. Lorenson and W. Evans for gas analyses; the staff of the Hawaiian Volcano Observatory for logistical support, and the anonymous reviewers for helpful comments. This research was supported by the U.S. Office of Naval Research (grant N00014-90-J-1805), the Hawaii Undersea Research Laboratory, and the University of Hawaii Sea Grant College Program (to G. McMurtry). School of Ocean and Earth Science and Technology publication No. 2492.

\section{References}

Baker, E.T., and G.J. Massoth, Hydrothermal plume measurements: a regional perspective, Science, 234, 980-982, 1986.

Baker, E.T., G.J. Massoth, and R.A. Feely, Cataclysmic hydrothermal venting on the Juan de Fuca Ridge, Nature, 329, 149-151, 1987.

Baker, E.T., F.W. Lavelle, R.A. Feely, G.J. Massoth, and S.L. Walker, Episodic venting of hydrothermal fluids from the Juan de Fuca Ridge, J. Geophys. Res., 94, 9237-9250, 1989.

Bischoff, J.L., and R.J. Rosenbauer, An empirical equation of state for hydrothermal seawater (3.2 percent $\mathrm{NaCl}), A m$. J. Sci., 285, 725-763, 1985.

Brooks, J.M., D.F. Reid, and B.B. Bernard, Methane in the upper water column of the northwestern Gulf of Mexico, J. Geophys. Res., 86, 11029-11040, 1981.

Bullister, J.L., N.L. Guinasso, and D.R. Schink, Dissolved hydrogen, carbon monoxide, and methane at the CEPEX site, J. Geophys. Res., 87, 2022-2034, 1982.

Carnrick, G.R., W. Slavin, and D.C. Manning, Direct 
determination of manganese in seawater with the L'vov platform and Zeeman background correction in the graphite furnace, Anal. Chem., 53, 1866-1872, 1981.

Charlou, J.L., L. Dmitriev, H. Bougault, and H.D. Needham, Hydrothermal $\mathrm{CH}_{4}$ between $12^{\circ} \mathrm{N}$ and $15^{\circ} \mathrm{N}$ over the MidAtlantic Ridge, Deep-Sea Res., 35, 121-131, 1988.

Christie, D.M., I.S. Carmichael, and C.H. Langmuir, Oxidation states of mid-ocean basalt glasses, Earth Planet. Sci. Lett., 79, 397-411, 1986.

Converse, D.R., H.D. Holland, and J.M. Edmond, Flow rates in the axial hot springs of the East Pacific Rise $\left(21^{\circ} \mathrm{N}\right)$ : implications for the heat budget and the formation of massive sulfide deposits, Earth Planet. Sci. Lett., 69, 159-175, 1984.

Corliss, J.B., and coworkers, Submarine thermal springs on the Galapagos Rift, Science, 203, 1073-1083, 1979.

Crisp, J.A., Rates of magma emplacement and volcanic output, $J$. Volcanology Geothermal Res., 20, 177-211, 1984.

Davis, E.E., Evidence for extensive basalt flows on the sea floor, Geol. Soc. America Bull., 93, 1023-1029, 1982.

Deming, H.G., General Chemistry: An Elementary Survey Emphasizing Industrial Applications of Fundamental Principles, pp. 99-100, Wiley \& Sons, N.Y., 1935.

Gamo, T., J.-I. Ishibashi, H. Sakai, and B. Tilbrook, Methane anomalies in seawater above the Loihi submarine summit area, Hawaii, Geochim. Cosmochim. Acta, 51, 2857-2864, 1987.

Gerlach, T.M., Chemical characteristics of the volcanic gases from Nyiragongo lava lake and the generation of $\mathrm{CH}_{4}$-rich fluid inclusions in alkaline rocks, J. Volcanology Geothermal Res., 8, 177-189, 1980.

Gerlach, T.M., and B.E. Taylor, Carbon isotope constraints on degassing of carbon dioxide from Kilauea Volcano, Geochim. Cosmochim. Acta, 54, 2051-2058, 1990.

Greenland, L.P., Hawaiian eruptive gases, in Volcanism in Hawaii, edited by R.W. Decker et al., pp. 759-770, U.S. Geological Survey Prof. Paper 1350, Washington, D.C., 1987.

Greenley, R., The role of lava tubes in Hawaiian volcanoes, in Volcanism in Hawaii, edited by R.W. Decker et al., p. 1589, U.S. Geological Survey Prof. Paper 1350, Washington, D.C., 1987.

Jenkins, W.J., J.M. Edmond, and J. Corliss, Excess ${ }^{3} \mathrm{He}$ and ${ }^{4} \mathrm{He}$ in Galapogos submarine hydrothermal waters, Nature, 272, 156$158,1978$.

Jørgensen, B.B., The production and fate of reduced C, N, and S gases from oxygen-deficient environments, in Atmospheric Chemistry, edited by E.D. Goldberg, pp. 215-229, SpringerVerlag, Berlin, 1982.

Kadko, D.C., N.D. Rosenberg, J.E. Lupton, R.W. Collier, and M.D. Lilley, Chemical reaction rates and entrainment within the Endeavour Ridge hydrothermal plume, Earth Planet. Sci. Lett., 99, 315-335, 1990.

Kelly, K.M., K. Hon, and G.W. Tribble, Bathymetric and submarine studies of an active lava delta near Kupapau Point, Kilauea Volcano, Hawaii, Eos, 70, 1202, 1989.

Lilley, M.D., J.A. Baross, and L.I. Gordon, Reduced gases and bacteria in hydrothermal fluids: the Galapogos Spreading Center and $21^{\circ} \mathrm{N}$ East Pacific Rise, in Hydrothermal Processes at
Seafloor Spreading Centers, edited by P.A. Rona et al., pp. 411-449, Plenum, NY, 1983.

McClelland, L., T. Simkin, M. Summers, E. Nielsen, and T.C. Stein, Global Volcanism 1975-1985, 657 pp., Prentice Hall, Englewood Cliffs, N.J., 1989.

Parsons, T.R., Y. Maita, and C.M. Lalli, A Manual of Chemical and Biological Methods for Seawater Analysis, 173 pp., Pergamon, Oxford, 1984.

Sansone, F.J., J.B. Culp, and R.L. Pyle, Pele Meets the Sea, LavaVideo Productions, Honolulu, Hi. $27 \mathrm{~min}$. videotape, 1990a.

Sansone, F.J., G.W. Tribble, K.M. Kelly, J.A. Resing, P.N. Sedwick, and K. Hon, Nearshore lava-seawater interactions at Kupapau Point, Hawaii, Eos, 71, 144, 1990b.

Sedwick, P.N., G.M. McMurtry, and G.W. Tribble, Hydrothermal alteration of seawater by lava during the $1989 \mathrm{Pu}$ 'u O'o eruption of Kilauea Volcano, Hawaii. Mar. Geol., 96, 151-158, 1991.

Seyfried, W.E., D.R. Janecky, and M.J. Mottl, Alteration of the oceanic crust: Implications for geochemical cycles of lithium and boron. Geochim. Cosmochim. Acta, 48, 557-569.

Shaw, H.R., and J.G. Moore, Magmatic heat and the El Niño cycle, Eos, 69, 1553-1567, 1988.

Stoughton, R.W., and M.H. Lietzke, Thermodynamic properties of sea salt solutions, J. Chem. Eng. Data, 12, 101-104, 1967.

Tribble, G.W., Underwater observations of active lava flows from Kilauea Volcano, Hawaii, Geology, 1991 (in press).

Von Damm, K.L., J.M. Edmond, B. Grant, C.I. Measures, B. Walden, and R.F. Weiss, Chemistry of submarine hydrothermal solutions at $21^{\circ} \mathrm{N}$, East Pacific Rise, Geochim. Cosmochim. Acta, 49, 2197-2220, 1985.

Von Damm, K.L., and J.L. Bischoff, Chemistry of hydrothermal solutions from the southern Juan de Fuca Ridge, J. Geophys. Res., 92, 11334-11346, 1987.

Welhan, J.A., and H. Craig H., Methane, hydrogen, and helium in hydrothermal fluids at $21^{\circ} \mathrm{N}$ on the East Pacific Rise, in Hydrothermal Processes at Seafloor Spreading Centers, edited by P.A. Rona et al., pp. 391-409. Plenum, NY., 1983.

Wolfe, E.W., M.O. Garcia, D.B. Jackson, R.Y. Koyanagi, C.A. Neal, and A.T. Okamura, The Puu Oo eruption of Kilauea Volcano, episodes 1-20, January 3, 1983, to June 8, 1984, in Volcanism in Hawaii, edited by R.W. Decker et al., p. 471, U.S. Geological Survey Prof. Paper 1350, Washington, D.C., 1987.

K. Hon, Hawaiian Volcano Observatory, P.O. Box 51, Volcano, HI 96718 (Present address: U.S. Geological Survey, MS-903, Federal Center, Denver, CO 80225).

K. M. Kelly, J. A. Resing, F. J. Sansone, and P. N. Sedwick, Department of Oceanography, University of Hawaii at Manoa, 1000 Pope Road, Honolulu, HI 96822.

G. W. Tribble, U.S. Geological Survey, 677 Ala Moana Blvd., Suite 415, Honolulu, HI 96813.

(Received February 12, 1991; revised April 30, 1991 accepted May 2, 1991.) 